\title{
Acknowledgment to Reviewers of Crops in 2021
}

\section{Crops Editorial Office}

Citation: Crops Editorial Office.

Acknowledgment to Reviewers of

Crops in 2021. Crops 2022, 2, 40-41.

https://doi.org/10.3390/crops2010004

Published: 9 February 2022

Publisher's Note: MDPI stays neutral with regard to jurisdictional claims in published maps and institutional affiliations.

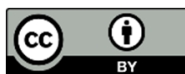

Copyright: () 2022 by the author. Licensee MDPI, Basel, Switzerland. This article is an open access article distributed under the terms and conditions of the Creative Commons Attribution (CC BY) license (https://creativecommons.org/licenses/by/4.0/).

MDPI AG, St. Alban-Anlage 66, 4052 Basel, Switzerland

Rigorous peer-reviews are the basis of high-quality academic publishing. Thanks to the great efforts of our reviewers, Crops was able to maintain its standards for the high quality of its published papers. Thanks to the contribution of our reviewers, in 2021, the median time to first decision was 17 days and the median time to publication was 39 days. The editors would like to extend their gratitude and recognition to the following reviewers for their precious time and dedication, regardless of whether the papers they reviewed were finally published:

Agata Motyka-Pomagruk

Aleksandra Duda-Chodak

Alexander Betekhtin

Alison Dann

Aliyeh Salehi

Ana Arnaiz

Andrzej Salata

Anna Vittoria Carluccio

Anuj Kumar

Attiq Ur Rehman

Ayalew Ligaba-Osena

Boris Lazarević

Carla Rolo Antunes

Christophe Hano

Daniela Sánchez Aldana

Dariusz Gozdowski

Dasha Mihaylova

Dieter Trautz

Dorukalp Durmus

Elisabetta Mazzucotelli

Emanuele Radicetti

Emidio Albertini

Emily Cantonwine

Eva Varallyay

Francesco Lops

Giampiero Cai

Goran Malidza

Guadalupe Guerra-Sanchez

Ioannis Roussis

Irina Anisimova

Isabel Duarte
István Papp

James Mwendwa

Janusz Podleśny

Jianhong Li

Jitka Kumhálová

Jong Hee Lee

Jose M. Mulet

Katarzyna Janda

Kyeong-Yeoll Lee

Lăcrămioara Oprică

Lisa Giacomelli

Maheteme Gebremedhin

Mara Elisa Soares De Oliveira

Maria De Fátima Oliveira

Masoud Hashemi

Monirul Islam

Nuria De Diego

Oksana Lastochkina

Olga Mykhailenko

Oskar Siemianowski

Pedro Vicente Mauri

Piotr Szulc

Ranjita Thapa

Renata Kuśmierek-Tomaszewska

Rosario Nicoletti

Rupesh Deshmukh

Satyabrata Nanda

Shahbaz Khan

Sławomir Michałek

Stan Lipovetsky

Swapna Priya Rajarapu 
Thomas Depaepe

Thomas Ingram

Tiphaine Vidal

Uttam Bhattarai

Varga Balázs
Victor Rodov

Vincent Tsai

Ying-Hong Lin

Yousry Bayoumi 